\title{
Application of MALDI-TOF mass spectrometry for study on fibrillar and oligomeric aggregates of alpha-synuclein
}

\author{
O. V. Severinovskaya ${ }^{1}$, V. B. Kovalska ${ }^{2}$, M. Yu. Losytskyy ${ }^{2}$, V. V. Cherepanov ${ }^{3}$,
} V. Subramaniam ${ }^{4}$, S. M. Yarmoluk ${ }^{2}$

${ }^{1}$ O. O. Chuiko Institute of Surface Chemistry, NAS of Ukraine

17, Generala Naumova Str., Kyiv, Ukraine, 03164

${ }^{2}$ Institute of Molecular Biology and Genetics, NAS of Ukraine

150, Akademika Zabolotnoho Str., Kyiv, Ukraine, 03143

${ }^{3}$ Institute of Physics, NAS of Ukraine

46, Nauky Ave., Kyiv, Ukraine, 03028

${ }^{4}$ Nanobiophysics Group, MESA + Institute for Nanotechnology and MIRA Institute for Biomedical Technology, University of Twente PO Box 217, 7500 AE Enschede, The Netherlands

severinovskaya.o@gmail.com

\begin{abstract}
Aim. To study the $\alpha$-synuclein (ASN) aggregates of different structural origin, namely amyloid fibrils and spherical oligomers, in comparison with a native protein. Methods. MALDI TOF mass spectrometry and atomic force microscopy (AFM). Results. The mass spectra of native and fibrillar ASN have similar character, i. e. they are characterized by the well pronounced peak of protein molecular ion, the low molecular weight associates, and rather low contain of fragmentation products. The spectrum of oligomeric aggregate is characterized by the high contain of fragmentation products, low intensity of protein molecular ion and the absence of peaks of associates. Conclusions. The difference between the spectra of fibrillar and oligomeric ASN could be explained, first, by the different content of the «residual» monomeric ASN and the protein degradation products in the studied samples, and, second, by the different structure-depended mechanisms of the protein degradation induced by the laser ionization. We suggested that the MALDI-TOF mass spectroscopy is a method useful for the investigation of ASN aggregation and characterization of its high order self-associates; besides, there is an interest in estimating the potency of the MALDI-TOF for the analysis of aggregation of various amyloidogenic proteins.
\end{abstract}

Keywords: alpha-synuclein, MALDI-TOF, amyloid fibril, oligomeric aggregate, AFM.

Introduction. Pathogenesis of some harmful disorders among them neurodegenerative disorders (Parkinson, Alzheimer's diseases), prion diseases, type II diabetes is associated with the spontaneous uncontrolled protein aggregation, particularly with the formation of amyloid fibrils. Besides, a wide range of proteins, not involved in a certain disease, are able to form amyloid aggregates [1]. Thefore, the study on the protein aggregation is an actual biomedical task.

(c) Institute of Molecular Biology and Genetics, NAS of Ukraine, 2014
Among the methods of protein analysis the MALDITOF mass spectrometry is known as a popular and versatile tool [2]. In the proteomics, particularly in the studies on protein non-controlled aggregation, MALDITOF is mostly applied for the identification of protein origin by a proteolysis-based mass mapping method $[3,4]$.

The method of direct (excluding proteolysis digestion) MALDI-TOF has a low descriptiveness for the characterization of the protein high-molecular aggregates and was applied to analyze the fibrillization in- 
termediates and side products, $e . g$. the misfolded beta-lactoglobuline dimers and protein degradation products [5].

Alpha-synuclein (ASN) is a small natively unfolded protein that plays a central role in the etiology of Parkinson's disease. It forms amyloid fibrils that are found in Lewy bodies, i. e. cell depositions in the brain that are characteristic of this disease [6, 7]. Besides, during the aggregation process ASN forms small oligomeric intermediates, which are considered as presumably toxic species [8-10].

Here we report the examination of the ASN aggregates populations of different structural origin, namely amyloid fibrils and spherical oligomers, by the method of MALDI-TOF mass spectrometry. We suggest that the filamentous amyloid fibrils and spherical oligomers due to the distinct folding of the protein molecules and association/degradation on the aggregation pathway could possess the mass spectra of different character. Besides, we intend to evaluate the applicability of MALDI-TOF as a method for the analysis of protein aggregates and study on the aggregation process.

Materials and methods. Reagents. Recombinant human wild-type ASN was expressed and purified in $10 \mathrm{mM}$ Tris- $\mathrm{HCl}, 50 \mathrm{mM} \mathrm{NaCl}(\mathrm{pH} 7.4)$ as described earlier [11]. ASN amyloid fibrils and oligomers were obtained according to [11] and [12] correspondingly.

MALDI-TOF studies. The samples of native, fibrillar and oligomeric ASN were prepared for the MALDITOF analysis as follows: matrix material (12 $\mathrm{mg}$ of 3 , 5-dimethoxy-4-hydroxycinnamic (sinapinic) acid) was dissolved in $1 \mathrm{ml}$ of water/acetonytyl solution 1:1 (v/v) with addition of $0.1 \%(\mathrm{v} / \mathrm{v})$ of trifluoroacetic acid. The obtained solution was incubated during $10 \mathrm{~min}$ at $30^{\circ} \mathrm{C}$ in ultrasonic bath up to the full dissolving of the acid. [13]. The $50 \mu \mathrm{mol}$ protein samples in $0,05 \mathrm{M}$ Tris- $\mathrm{HCl}$ buffer ( $\mathrm{pH} 7.9$ ) with concentration of $1 \mathrm{mg} / \mathrm{ml}$ were then added to the matrix solution in 1:1 ratio. Small aliquots of the mixture were applied to the steel probe tips and dried. Mass analysis was performed on the «Autoflex II» («Bruker Daltonics», Germany) MALDI-TOF mass spectrometer with nitrogen laser $(\lambda=337 \mathrm{~nm})$. Spectra were obtained for the mass range 7000 to 100 $000 \mathrm{~m} / \mathrm{z}$. in positive ion reflectron registration mode. The spectra were obtained by summing the data of 100 laser shots.
Atomic force microscopy studies. The structure of ASN aggregates was studied by means of AFM («Solver Pro M» system, NT-MDT, RF). The scanning rate was $30 \mu \mathrm{m} / \mathrm{s}$. For the formation of subnanolayer consisting of separate nanoobjects, the reaction solutions were diluted 30 times with bidistilled water. Then a drop of the solution was applied on the freshly cleaved surface of mica. The AFM measurements were carried out in a tapping mode at ambient conditions after the full evaporation of the solvent. The AFM probes of type NSG01 (NT-MDT) were used. The average diameter values of ASN aggregates were determined based on their heights in the AFM images.

Results and discussion. Structural peculiarities of native, fibrillar and oligomeric ASN. ASN is a small (140 amino acids) protein that is known to be natively unfolded in solutions. The protein's amino acid sequence consists of a basic $\mathrm{N}$-terminal region (residues 1-95) containing repeats of highly conserved KTKEGV hexameric motif, and an acidic $\mathrm{C}$-terminal region (residues 96-140) [14], the first 100 residues are predicted to have $\alpha$-helical propensity [15].

Amyloid fibrils are stable protein aggregates, with cross- $\beta$ filament structure where the protein molecules, making up the $\beta$-sheet, are arranged perpendicular to the fibril axis [16]. The core of the ASN fibril contains mainly the protein residues of the basic region (approximately residues 38-95 [17]). We have estimated the characteristics of the ASN fibrils population by AFM. These fibrils are both linear and branched long filaments with the diameter of single filament about $3-8 \mathrm{~nm}$ (Fig. 1). The bundles of fibrils formed by overlapping of single filaments were observed in the studied sample as well. The strong fluorescent sensitivity of the amyloidspecific cyanine dye 7519 to the ASN fibrils was previously reported [18].

The ASN oligomers are known as spherical protein aggregates of the size in the range 2-20 $\mathrm{nm}$ [19-21], besides, the structures with annular and tubular morphology have also been reported [21-23].

Our AFM study demonstrated the ASN oligomer population to be mostly the species of the height from 3 till $6 \mathrm{~nm}$ (Fig. 2). Besides, the structures formed due to the coalescence of these aggregates are observed; the diameter of such «super-oligomeric» structures being up to $10 \mathrm{~nm}$. 

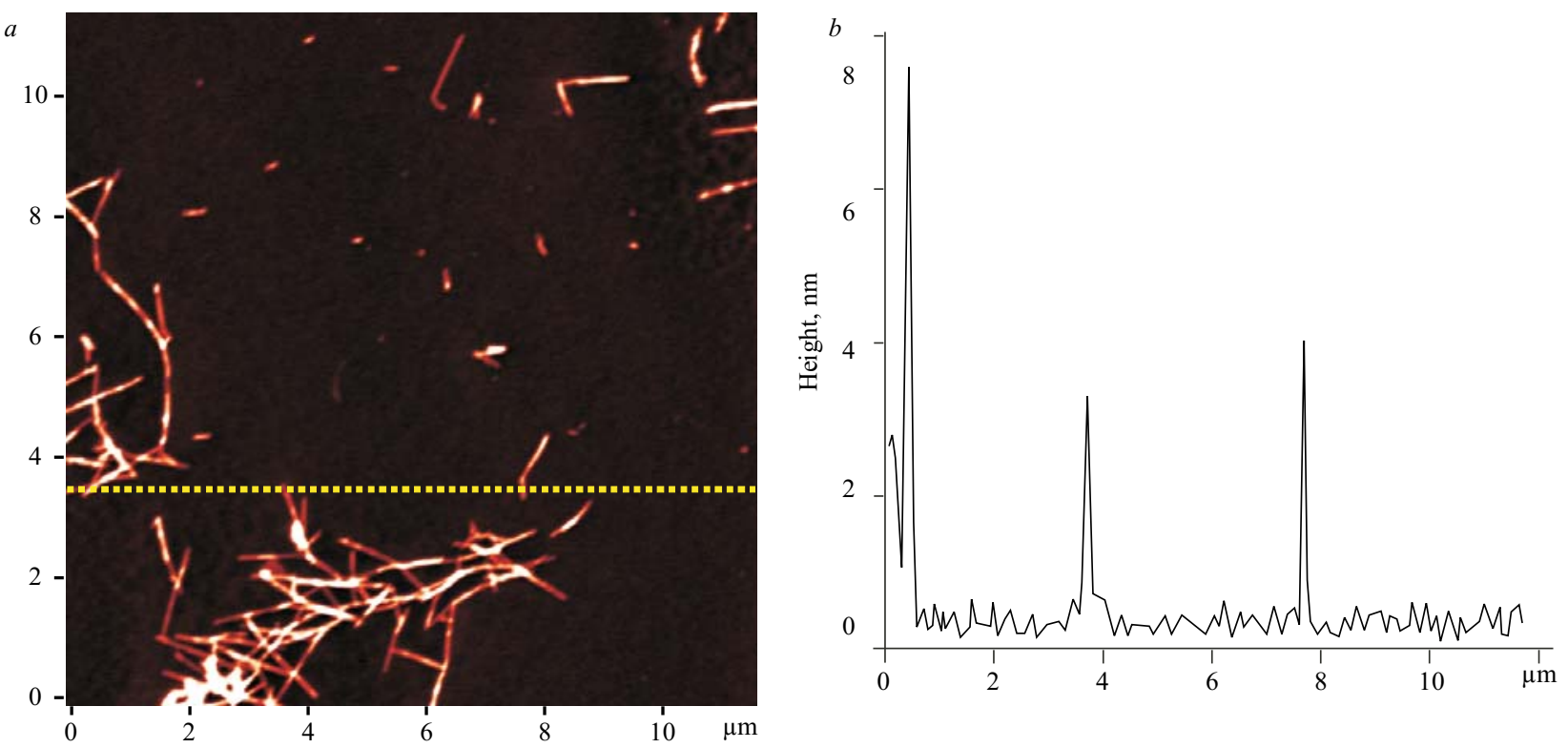

Fig. 1. AFM image of amyloid fibril of ASN ( $a$ ) and Z-profile along the line marked on the image $(b)$
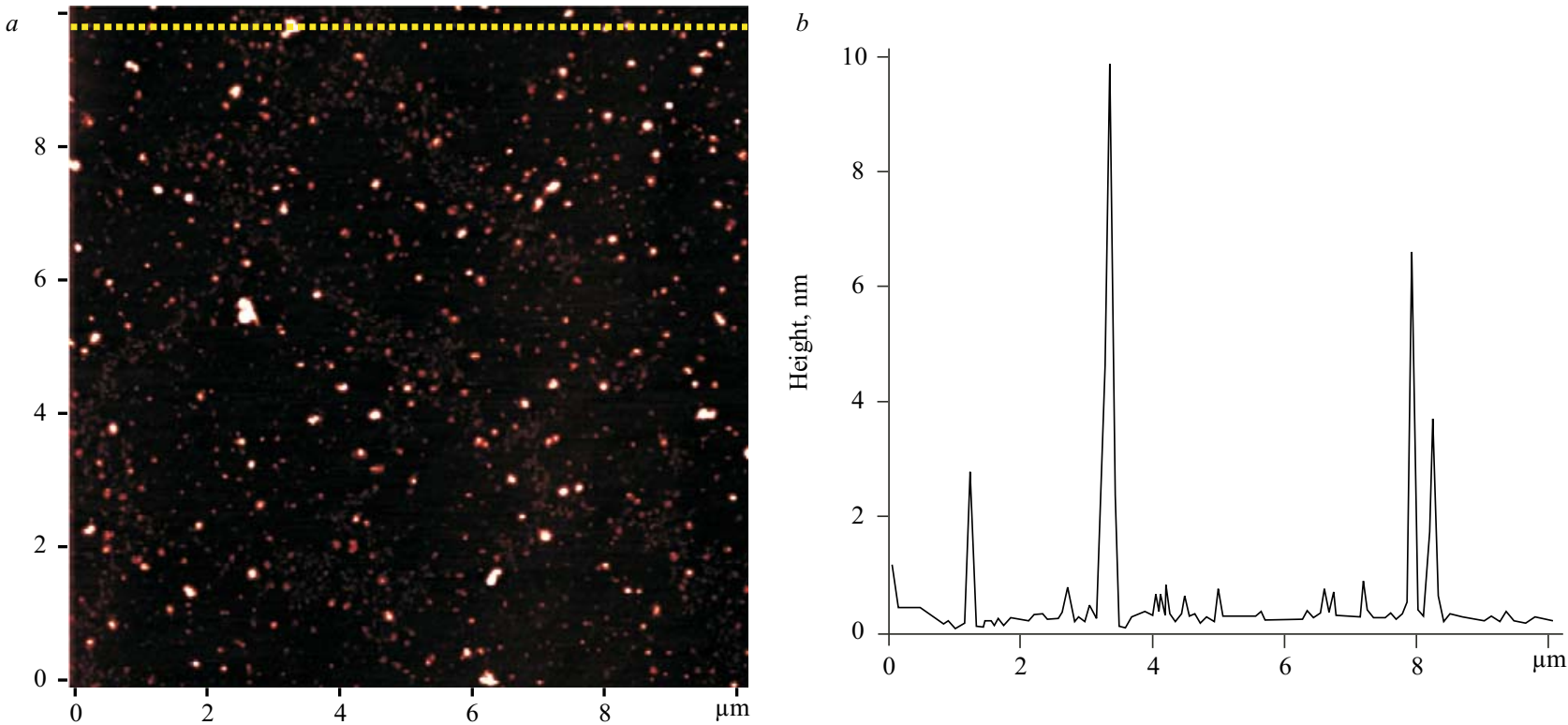

Fig. 2. AFM image of oligomer aggregates of $\operatorname{ASN}(a)$ and Z-profile along the line marked on the image $(b)$

Despite the oligomer aggregates are mainly considered to possess beta-sheet structure [24, 25], the presence of $\alpha$-helical content has been shown as well [19]. The difference between the secondary structure motifs of amyloid fibrils and oligomeric aggregates is indicated by the different sensitivity of amyloid-specific cyanine dyes to these ASN formations [26]. The noticeably lower fluorescent response of the dyes on the presence of oligomers comparing to fibrils is explained by the lower content of beta-pleated regions accessible for the dye molecules.

MALDI-TOF studies. The mass spectra of native, fibrillar and oligomeric ASN are presented in Fig. 3. All spectra contain the peaks corresponding to the protein molecular ion about $14460 \mathrm{~m} / \mathrm{z}$ and a wide range of protein fragmentation peaks, but only two of these peaks 
Table 1

Protein fragments and associates observed in mass spectra of native and aggregated ASN

\begin{tabular}{c|c|c|c|c}
\hline \multirow{2}{*}{ Fragment } & \multirow{2}{*}{ Mass, $\mathrm{m} / \mathrm{z}$} & Native & Oligomer & Fibril \\
\cline { 3 - 5 } & 72170 & $I$, a. u. & I, a. u. & I, a. u. \\
\hline$[5 \mathrm{M}]^{+}$ & 57720 & 280 & - & - \\
{$[4 \mathrm{M}]^{+}$} & 43260 & 734 & - & 739 \\
{$[3 \mathrm{M}]^{+}$} & 28860 & 2234 & - & 2681 \\
{$[2 \mathrm{M}]^{+}$} & 14460 & 9808 & 1672 & 40648 \\
{$[\mathrm{M}]^{+}$} & 13720 & 66459 & 1167 & 9148 \\
$\mathrm{~F} 1$ & 10630 & 6441 & 3427 & 8407 \\
\hline $\mathrm{F} 2$ & 3379 & & \\
\hline
\end{tabular}

N o t e. Mass - observed mass of the peaks; $I-$ intensity of peaks; a. u. - arbitrary units; $[\mathrm{M}]^{+}-$molecular ion; $[n \mathrm{M}]^{+}($where $\mathrm{n}=2-5)-$ molecular associates of ASN containing $n$ protein molecules; F1 and F2 - fragments that are common for all protein forms.

Table 2

Ratio between intensities of ASN fragments and molecular ion peaks

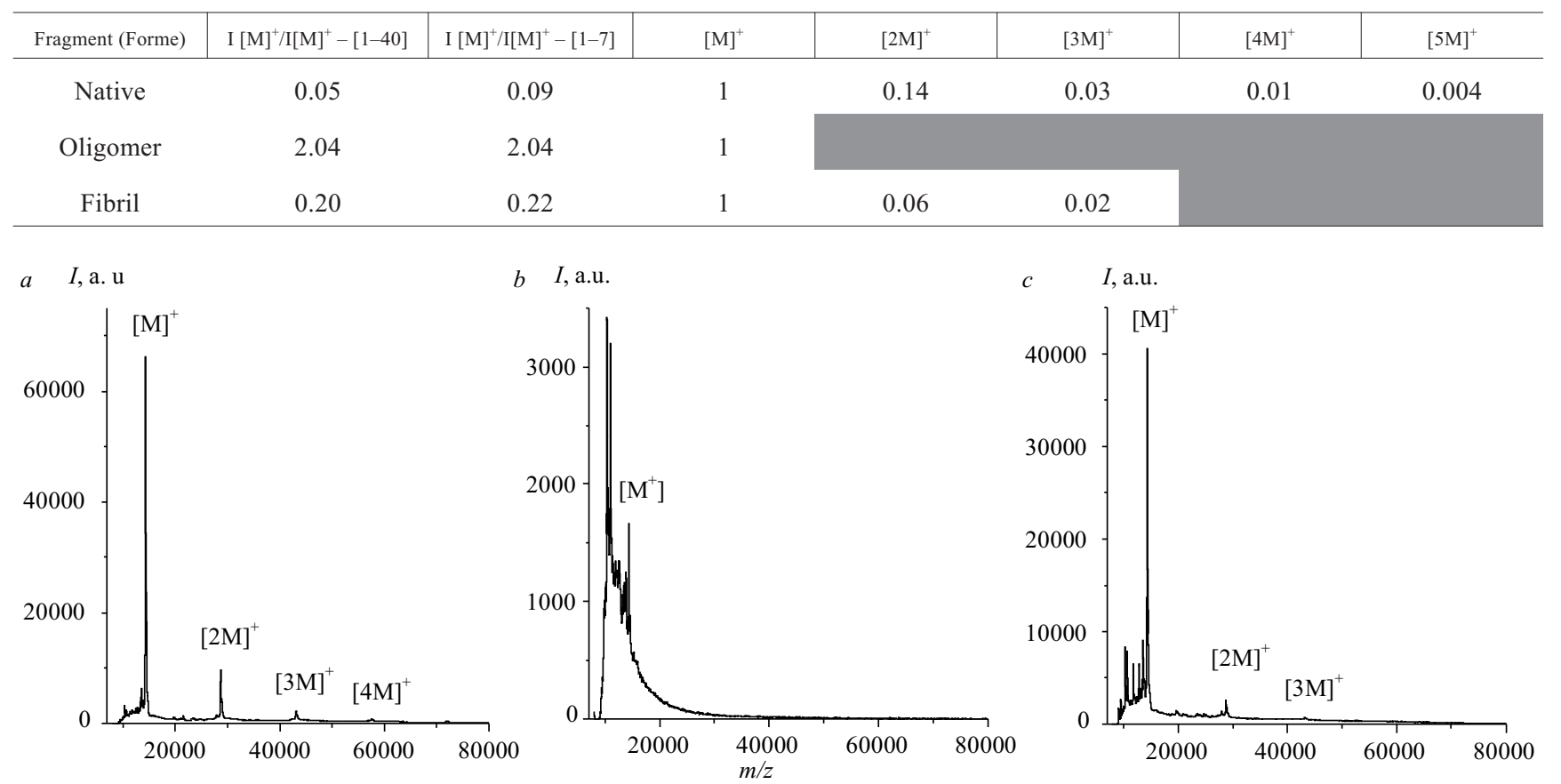

Fig. 3. General mass spectrum of native (a), oligomeric (b) and fibrillar (c) ASN

(about 13720 and $10630 \mathrm{~m} / \mathrm{z}$ ) are common for all protein forms.

The peaks corresponding to low-order associates were detected only for native and fibrillar ASN. Thus, we suggest that the protein mass-spectra depend on its association degree and folding type (native ASN, oligomer or fibril).
Molecularion and protein as sociates. In the mass spectrum of native ASN the molecular ion peak with molecular mass about $14460 \mathrm{~m} / \mathrm{z}$ is the most intensive and highly resolved, it contains satellite shoulder corresponding to an associate of ASN molecule with the matrix one (sinapic acid). The mass spectrum is characterized by insignificant content of the protein frag- 

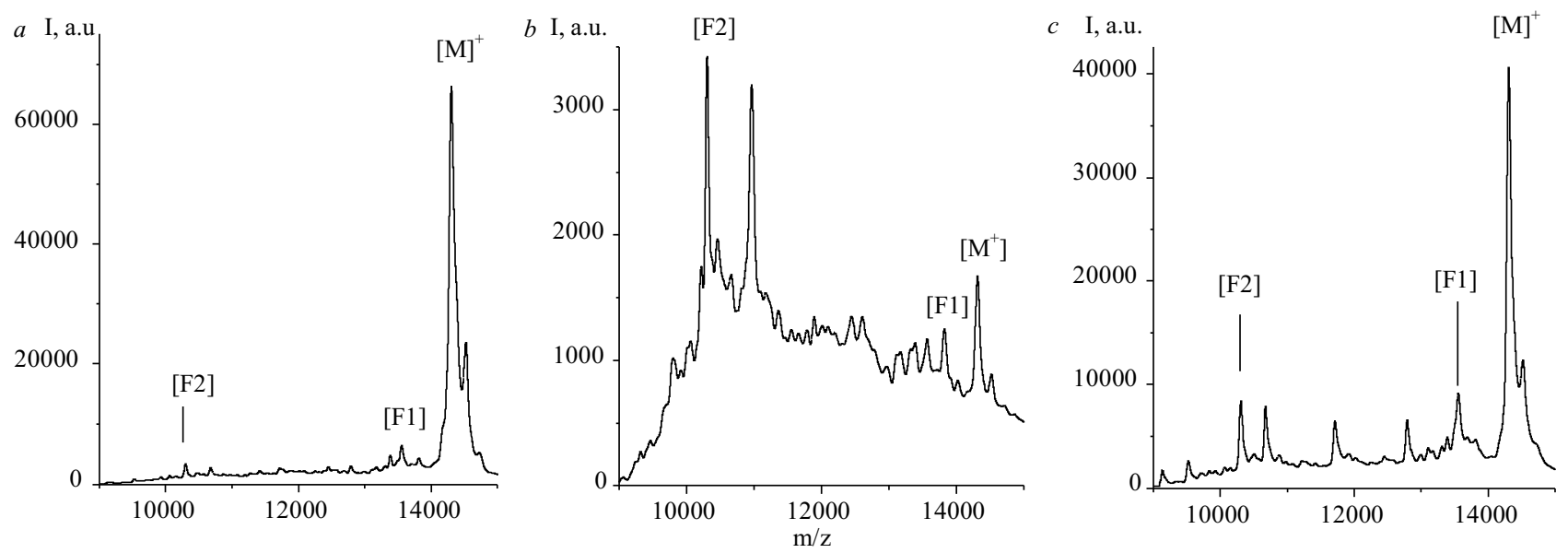

Fig. 4. Representative mass spectra of native (a), oligomeric (b) and fibrillar ASN (c) in molecular mass region 9000-15000 m/z

$\begin{array}{cccccc}10 & 20 & 30 & 40 & 50 & 60 \\ \text { MDVFMKGLSK AKEGVVAAAE } & \text { KTKOGVAEAA } & \text { GK TKEGVLYV GSK TKEGVVH VATVAEKTK } \\ 70 & 80 & 90 & 100 & 110 & 120 \\ \text { EOVTN VG GAV VTGVTAVAOK TVEGAGSIAA ATGFVKKDOL GKNEEGAPOE GILEDMPVDP } \\ 130 & 140 & & & \\ \text { DNEAYEMPSE EG YODYEPEA } & & \end{array}$

Fig. 5. Sequence of human ASN (from uniprot.db, entry P37840)

mentation products. The series of peaks with the intensities decreasing upon the mass increase are detected in the high mass region; they correspond to the protein molecular associates from dimer to pentamer with molecular masses about 28860, 43260, 57720 and $72170 \mathrm{~m} / \mathrm{z}$, correspondingly (Table 1,2). The association is caused by intermolecular interactions and is typically observed in the MALDI-TOF mass spectra of different proteins (albumin, insulin, lysozime etc.) [4, 13], the formation of ASN dimer, trimer and tetramer was also described [15].

In the fibrillar protein spectrum, similarly to that of the native ASN, the peak of molecular ion is the most intensive. The low order associates are also presented in the spectrum, but the number of aggregated molecules (only dimers and trimers were observed) and intensity of peaks are lower than for the native protein. On the other hand, the number and intensity of the peaks of fragmentation products for the fibrillar ASN is enhanced as compared to the native protein.

The mass spectrum of oligomer significantly differs from that of native and fibrillar protein. It is characteri- zed by a very high fragmentation degree (the peak of molecular ion is less intensive than the main peaks of fragmentation products) and by the absence of associates peaks.

The fragmentation products. In the mass spectrum of the native, fibrillar and oligomeric ASN the wide range of protein fragmentation product is detected (Fig. 4, Table 1,2). However, only two of them with molecular masses about 13720 and $10630 \mathrm{~m} / \mathrm{z}$ (F1 and F2 correspondingly), are common for all protein forms.

The content of fragmentation products in the native ASN mass spectrum is quite low, the peaks with $\mathrm{m} / \mathrm{z}$ of about $13980,13720,10830$ and 10630 correspond to the major fragmentation products of ASN molecule.

In the case of fibrillar ASN the content of protein fragmentation products is much higher than in the mass spectrum of native protein, the major peaks with $\mathrm{m} / \mathrm{z}$ of about 13720, 12950, 11870, 10830, 10630, 9680 and 9300 were detected.

In the oligomeric ASN spectrum the wide poorly resolved bands of protein fragmentation products dominate. The two peaks of about $11130 \mathrm{~m} / \mathrm{z}$ and $13980 \mathrm{~m} / \mathrm{z}$ 
are twice more intensive than this of the molecular ion of ASN. Another intensive peak of about $10630 \mathrm{~m} / \mathrm{z}$ is also present in the spectra of native and fibrillar ASN. The fragment with $\mathrm{m} / \mathrm{z}$ about 13720 that is common for all protein forms has low intensity in spectra of oligomeric aggregate.

Explanations of a distinct character of the fibrillar and oligomeric ASN mass-spectra. We could propose two explanations of the distinctions in the mass-spectra of fibrillar and oligomeric ASN.

The first explanation is that the similarity of the native and fibrillar ASN mass specta is caused by the presence of an excess of non-aggregated protein in the fibrillar ASN sample. Since the ASN monomeric molecules are easily ionized they give a high intensive peak of the molecular ion and associates.

The distinction between the fragmentation of fibrils and oligomers could be caused by the presence of specific degradation products formed during the aggregation reaction or later storage of the samples.

Another possible explanation is dissimilarity in the folding of protein molecules in the amyloid fibrils and the oligomeric species and different structure of these aggregates.

It may be supposed that due to their regular ladderlike structure the degradation of the amyloid fibrils upon ionization in a large extent occurs through the tearing off the intact protein molecules from the end (one by one) of the filament. These protein molecules are responsible for an intensive peak of the molecular ion and peaks of the low-ordered associates.

Besides, the laser-induced degradation could occur through a break in the protein chain, that leads to the appearance of new intensive bands of the protein fragmentation products. This mechanism is proved by higher number, content and lower resolution of the protein fragment peaks in the spectrum of fibrils comparing with the native ASN.

The large content of fragmentation products in the spectrum of the oligomeric aggregates and their low resolution may be explained by the poor ionization and poor stability of these structures. We assume that due to their spherical shape the oligomeric aggregates degraded through the lost of protein fragments from the opened surface regions. The suggestion about the hindered ability of degradation of the oligomeric aggregate through the tearing off a whole protein molecule is supported by the very low intensity of molecular ion.

О. В. Севериновська, В. Б. Ковальська, М. Ю. Лосицький,

В. В. Черепанов, В. Субраманіам, С. М. Ярмолюк

Використання методу MALDI-TOF масс-спектрометрії для вивчення фібрилярних та олігомерних агрегатів альфа-синуклеїну Резюме

Мета. Вивчення агрегатів альфа-синуклеїну (ASN) різного структурового походження, а саме - амілоїдних фібрил $і$ сферичних олігомерів порівняно з нативним білком. Методи. MALDI-TOF мас-спектрометрія та атомно-силова мікроскопія (AFM). Результати. Мас-спектри нативного і фібрилярного ASN мають подібний характер - для них характерні інтенсивний пік молекулярного іона білка, піки низькомолекулярних асоціатов та досить незначний вміст продуктів фрагментації білка. У той же час у спектрі олігомерних агрегатів спостерігаються висока концентрація продуктів фрагментації білка, низька інтенсивність молекулярного іона та відсутність піків самоасоціатів. Висновки. Різницю між спектрами фибрилярного та олігомерного ASN можна пояснити як наявністю у зразках «залишкового» ASN i продуктів деградаиії білка, так і різними структурово залежними механізмами руйнування цих двох видів агрегатів при лазерній десорбиії/іонізачії. MALDI-TOF мас-спектрометрію можна запропонувати як метод вивчення агрегачії та аналізу високомолекулярних агрегатів ASN. Також представляє інтерес визначення ефективності иього методу для дослідження агрегатів різних амілоїдогенних білків.

Ключові слова: альфа-синуклё̈н, MALDI-TOF, амілоїдна фібрила, олігомерні агрегати, AFM.

О. В. Севериновская, В. Б. Ковальская, М. Ю. Лосицкий, В. В. Черепанов, В. Субраманиам, С. Н. Ярмолюк

Использование метода MALDI-TOF масс-спектрометрии для изучения фибриллярных и олигомерных агрегатов альфа-синуклеина

Резюме

Цель. Изучение агрегатов альфа-синуклеина (ASN) различной структуры, а именно - амилоидных фибрилл и сферических олигомеров в сравнении с нативным белком. Методы. MALDI-TOF масс-спектрометрия и атомно-силовая микроскопия (AFM). Результатыл. Масс-спектры нативного и фибриллярного ASN имеют подобный характер - для них характерны интенсивный пик молекулярного иона белка, пики низкомолекулярных ассоциатов, а также достаточно незначительное содержание продуктов фрагментации белка. В то же время в спектре олигомерных агрегатов наблюдаются высокая концентрация продуктов фрагментации белка, молекулярный ион низкой интенсивности и отсутствие пиков ассочиатов белка. Выводы. Различие между спектрами фибриллярного и олигомерного $A S N$ можно объяснить как содержанием «избытка» $A S N$ и продуктов деградации белка, так и различными структурно-зависимыми механизмами разруцениями этих двух видов агрегатов при лазерной десорбции/ионизации. MALDI-TOF масс-спектрометрию можно предложить в качестве метода изучения агрегации и анализа высокомолекулярных агрегатов ASN. Также представляет интерес определе- 
ние эффективности MALDI-TOF для исследования агрегатов различных амилоидогенных белков.

Ключевые слова: альфа-синуклеин, MALDI-TOF, амилоидная фибрилла, олигомерные агрегаты, АFM.

\section{REFERENCES}

1. Green J, Goldsbury C, Mini T, Sunderji S, Frey P, Kistler J, Cooper $G$, Aebi $U$. Full-length rat amylin forms fibrils following substitution of single residues from human amylin. $J$ Mol Biol. 2003;326(4):1147-56.

2. Marvin LF, Roberts MA, Fay LB. Matrix-assisted laser desorption/ionization time-of-flight mass spectrometry in clinical chemistry. Clin Chim Acta. 2003;337(1-2):11-21.

3. Nazabal A, Weber J. Characterization and quantitation of antibody aggregates by high mass MALDI mass spectrometry. $J$ Biomol Tech. 2010; 21(3 Suppl): S36.

4. Metods in enzymology. Amyloid, prions and other protein aggregates, part C. Eds I. Kheterpal, R. Wetzel. Amsterdam, Elsevier Inc., 2006; Vol. 413. 375 p.

5. Hamada D, Dobson CM. A kinetic study of beta-lactoglobulin amyloid fibril formation promoted by urea. Protein Sci. 2002;11 (10):2417-26

6. Uversky $V N$. Neuropathology, biochemistry, and biophysics of alpha-synuclein aggregation. J Neurochem. 2007;103(1):17-37.

7. Bartels AL, Leenders KL. Parkinson's disease: the syndrome, the pathogenesis and pathophysiology. Cortex. 2009;45(8):915-21.

8. Lashuel HA, Petre BM, Wall J, Simon M, Nowak RJ, Walz T, Lansbury PT Jr. Alpha-synuclein, especially the Parkinson's disease-associated mutants, forms pore-like annular and tubular protofibrils. J Mol Biol. 2002;322(5):1089-102.

9. Volles MJ, Lansbury PT Jr. Zeroing in on the pathogenic form of alpha-synuclein and its mechanism of neurotoxicity in Parkinson's disease. Biochemistry. 2003;42(26):7871-8.

10. Volles MJ, Lee SJ, Rochet JC, Shtilerman MD, Ding TT, Kessler $J C$, Lansbury PT Jr. Vesicle permeabilization by protofibrillar alpha-synuclein: implications for the pathogenesis and treatment of Parkinson's disease. Biochemistry. 2001;40(26): 7812-9.

11. van Raaij ME, Segers-Nolten IM, Subramaniam V. Quantitative morphological analysis reveals ultrastructural diversity of amyloid fibrils from alpha-synuclein mutants. Biophys J. 2006;91 (11):L96-8.

12. van Rooijen BD, Claessens MM, Subramaniam V. Lipid bilayer disruption by oligomeric alpha-synuclein depends on bilayer charge and accessibility of the hydrophobic core. Biochim Biophys Acta. 2009;1788(6):1271-8.

13. Dekina SS, Romanovska II, Gromovoy TYu. Influence of polymers on lysozyme molecules association. Biopolym Cell. 2011; 27(6):442-445.
14. Sode K, Ochiai S, Kobayashi N, Usuzaka E. Effect of reparation of repeat sequences in the human alpha-synuclein on fibrillation ability. Int J Biol Sci. 2006;3(1):1-7.

15. Wang W, Perovic I, Chittuluru J, Kaganovich A, Nguyen LT, Liao J, Auclair JR, Johnson D, Landeru A, Simorellis AK, Ju S, Cookson MR, Asturias FJ, Agar JN, Webb BN, Kang C, Ringe D, Petsko GA, Pochapsky TC, Hoang QQ. A soluble $\alpha$-synuclein construct forms a dynamic tetramer. Proc Natl Acad Sci USA. 2011;108(43):17797-802.

16. Rambaran $R N$, Serpell LC. Amyloid fibrils: abnormal protein assembly. Prion. 2008;2(3):112-7.

17. Cho MK, Kim HY, Fernandez CO, Becker S, Zweckstetter M. Conserved core of amyloid fibrils of wild type and A30P mutant $\alpha$-synuclein. Protein Sci. 2011;20(2):387-95.

18. Volkova KD, Kovalska VB, Yu Losytskyy M, Veldhuis G, Segers-Nolten GM, Tolmachev OI, Subramaniam V, Yarmoluk SM. Studies of interaction between cyanine dye T-284 and fibrillar alpha-synuclein. J Fluoresc. 2010;20(6):1267-74.

19. Apetri MM, Maiti NC, Zagorski MG, Carey PR, Anderson VE. Secondary structure of alpha-synuclein oligomers: characterization by raman and atomic force microscopy. J Mol Biol. 2006; 355(1):63-71.

20. Conway KA, Lee SJ, Rochet JC, Ding TT, Williamson RE, Lansbury PT Jr. Acceleration of oligomerization, not fibrillization, is a shared property of both alpha-synuclein mutations linked to early-onset Parkinson's disease: implications for pathogenesis and therapy. Proc Natl Acad Sci US A. 2000;97(2):571-6.

21. Lashuel HA, Petre BM, Wall J, Simon M, Nowak RJ, Walz T, Lansbury PT Jr. Alpha-synuclein, especially the Parkinson's disease-associated mutants, forms pore-like annular and tubular protofibrils. J Mol Biol. 2002;322(5):1089-102.

22. Ding TT, Lee SJ, Rochet JC, Lansbury PT Jr. Annular alphasynuclein protofibrils are produced when spherical protofibrils are incubated in solution or bound to brain-derived membranes. Biochemistry. 2002;41(32):10209-17.

23. Quist A, Doudevski I, Lin H, Azimova R, $N g$ D, Frangione B, Kagan B, Ghiso J, Lal R. Amyloid ion channels: a common structural link for protein-misfolding disease. Proc Natl Acad Sci USA. 2005;102(30):10427-32.

24. Volles MJ, Lee SJ, Rochet JC, Shtilerman MD, Ding TT, Kessler $J C$, Lansbury PT Jr. Vesicle permeabilization by protofibrillar alpha-synuclein: implications for the pathogenesis and treatment of Parkinson's disease. Biochemistry. 2001;40(26):7812-9.

25. Kaylor J, Bodner N, Edridge S, Yamin G, Hong DP, Fink AL. Characterization of oligomeric intermediates in alpha-synuclein fibrillation: FRET studies of Y125W/Y133F/Y136F alpha-synuclein. J Mol Biol. 2005;353(2):357-72.

26. Kovalska VB, Losytskyy MY, Tolmachev OI, Slominskii YL, Segers-Nolten GM, Subramaniam V, Yarmoluk SM. Tri- and pentamethine cyanine dyes for fluorescent detection of $\alpha$-synuclein oligomeric aggregates. J Fluoresc. 2012;22(6):1441-8. 